\title{
Effect of low-dose mifepristone administration on day 2 after ovulation on transcript profiles in implantation-stage endometrium of rhesus monkeys
}

\author{
D Ghosh, A M Sharkey ${ }^{1}$, D S Charnock-Jones ${ }^{2}$, S K Smith ${ }^{3}$ and Jayasree Sengupta \\ Department of Physiology, All India Institute of Medical Sciences, New Delhi 110029, India, Departments of \\ ${ }^{1}$ Pathology and ${ }^{2}$ Obstetrics and Gynaecology, University of Cambridge, Cambridge CB2 2SW, UK and ${ }^{3}$ Faculty \\ of Medicine, Imperial College London, London SW7 2AZ, UK
}

Correspondence should be addressed to D Ghosh; Email: debabrata.ghosh1@gmail.com

\begin{abstract}
Progesterone is essential for endometrial receptivity in primates. In studies previously performed using global gene profiling based on microarray technology, attempts have been made to identify changes in gene expression between early luteal-phase and mid-luteal-phase endometria. However, the issue of the putative impact of preimplantation embryo-derived signal in the process of endometrial receptivity was missing in the previous studies. In the present study, an attempt has been made to delineate the transcripts profile in implantation-stage endometrium under combinatorial regulation of progesterone and embryo-derived signal in the rhesus monkey. To this effect, we have compared transcript profiles for 409 known genes between control receptive stage $(n=13)$, and mifepristone-induced desynchronized and non-receptive stage $(n=12)$ monkey endometrial samples collected on days $4(n=12)$ and $6(n=13)$ after ovulation from mated, potential conception cycles, using cDNA arrays containing sequence-verified clones. Statistical analysis of correlation of estimated transcript abundance between arrays and qRT-PCR for nine selected gene products yielded significant $(P<0.05)$ concordance. Of 409 genes, a total of 40 gene transcripts were seen to be affected, nine gene transcripts in endometrial samples were found to progressively increase between days 4 and 6 following mifepristone treatment, while an additional five genes showed differential expression profile depending on the day after treatment. Additionally, different sets of 12 and 14 gene products showed changes in days 4 and 6 post-ovulation samples respectively. A new cohort of 28 gene products in implantation-stage endometrium was seen to be affected by luteal-phase mifepristone.
\end{abstract}

Reproduction (2009) 138 357-370

\section{Introduction}

Typically, the mid-luteal phase of a normal mated ovulatory cycle provides the implantation window in the monkey and the human (Hendrickx \& Enders 1980, Edwards 1995). There are a few reports wherein the transcript profile of mid-luteal-stage endometrium has been compared with that of early luteal-stage endometrium to delineate the role of progesterone in establishing endometrial receptivity for embryo implantation (Carson et al. 2002, Kao et al. 2002, Borthwick et al. 2003, Riesewijk et al. 2003, Horcajadas et al. 2004). However, this model has a limitation; substantial biochemical and morphological evidence suggests that mid-luteal-phase endometrium exhibits phenotypically differential characteristics only in the presence of viable, synchronous embryo (Ghosh et al. 1993, Ghosh \& Sengupta 1998, 2004, Simon et al. 2000, Simon \& Dominguez 2004). Moreover, mifepristone administered at a relatively small dose (2 $\mathrm{mg}$ per $\mathrm{kg}$ body weight) in the early luteal stage renders endometrium phenotypically hostile during the implantation window resulting in implantation failure without any discernible change in serum concentrations of oestradiol and progesterone (Gemzell-Danielson et al. 1993, Ghosh \& Sengupta 1993). In the present study, we performed comparative analysis of selected transcript profiles between endometrial samples collected from fecund cycles of rhesus monkeys on days 4 and 6 after ovulation with and without mifepristone (2 mg per $\mathrm{kg}$ body weight) treatment on day 2 after ovulation. We report here for the first time that a set of genomic expression showed an overt differential regulation in implantationstage endometrium when it had been subjected to early luteal-phase treatment with high-affinity antiprogestin like mifepristone.

\section{Results}

Out of 36 animals who were assigned arbitrarily into control and treatment subgroups under both groups, two failed to show any clear indication of ovulation and 
six failed to yield any embryo on uterine flushing. Thus, preimplantation embryos between morula and blastocyst stages from the uteri of 28 animals could be retrieved and endometrial samples from these animals were collected for the present study. However, three samples were discarded because of the unacceptable quality of extracted RNA on quality assessment (Table 1). The details of the recovered embryos have been given elsewhere (Ghosh et al. 1997, 2000, Lalitkumar et al. 2005a).

Figure 1 shows the results of typical analysis of concordance of normalized expression profiles between control receptive endometrium and mifepristone-treated non-receptive endometrium on days 4 (Fig. 1A) and 6 (Fig. 1B) after ovulation. Overall, it reveals that the ranges of average expressions at the transcription level were relatively higher on day 6 after ovulation compared with that on day 4 after ovulation in both groups, presumably concurring with secretory-stage maturation of endometrium.

Statistical analysis of normalized, log-transformed, filtered cDNA array data of 409 gene products using conventional statistical tools identified that a total of 26 genes (20 increased and 6 decreased) on day 4 , and 28 genes (25 increased and 3 decreased) on day 6 after ovulation displayed statistically significant differential expression in endometrium as a result of mifepristone treatment on day 2 after ovulation in proven fertility cycles. As shown in Table 2, out of 409 genes relative abundance of transcripts of nine gene products (matrix metalloproteinase 9 (MMP9), STAT3, kinase domain receptor (KDR), tastin, RSP9, JUNB, leptin receptor, transforming growth factor $\beta-1$ (TGFB1) and RSP7) was higher in endometrial samples on both days 4 and 6 after ovulation following mifepristone treatment as compared with control samples and these showed a progressive increase between days 4 and 6 after ovulation in the mifepristone-treated group. A set of another 12 gene products showed changes only in day 4 post-ovulation samples, ten of them were increased and two showed decreased expression following mifepristone treatment (Table 2). Similarly, a different set of 14 gene products showed changes only in day 6 samples, 12 of them were increased and 2 were decreased following mifepristone treatment (Table 2). An additional five gene products were seen to express differentially depending on the day after treatment: transcript abundance for colony stimulating factor 1 (CSF1), RASA1, uteroferrin and uteroglobin were lower on day 4 after ovulation but reversed to become higher on day 6 after ovulation following mifepristone treatment while a reciprocal relationship was seen for enigma (Table 2). Statistical analysis based on gene expression statistical system software for repeated measures identified all 40 gene products to show differential changes, except three gene products (MMP9, CSF1 and RASA1) in samples collected from day 4 after ovulation (Table 2). Real-time quantitative RT-PCR verification for nine products using probes and primers as given in Table 3 confirmed the reliability of the observed changes in array analysis (Table 4).

Immunohistochemical examination for the protein products of JAK1 and activated STAT3 in endometrial samples collected on days 4 and 6 after fertilization with and without mifepristone treatment (Table 5, Figs 2 and 3 ) revealed that the immunopositive signals for JAK1 and PSTAT3 were consistently and markedly higher in the epithelial compartment $(P<0.01)$ compared with the stromal and vascular compartments on days 4 and 6 after ovulation, and mifepristone administration on day 2 after ovulation yielded a trend of reversing the profile resulting in lowered trend of score in the epithelial compartment and increased trend of score in stromal and vascular compartments.

\section{Discussion}

In the present study, we compared transcript profiles for known 409 genes between 'receptive', and mifepristone-induced desynchronized 'non-receptive'-stage monkey endometrial samples from mated, potential conception cycles, using cDNA arrays containing sequence-verified clones already known to be important in endometrial function. Out of 409 genes analysed following normalization, a total of $40(10 \%)$ gene transcripts were seen to be affected, $9(\sim 2 \%)$ gene transcripts in endometrial samples were found to

Table 1 Details of treatment groups.

\begin{tabular}{|c|c|c|c|c|c|}
\hline \multirow[b]{3}{*}{ Group } & \multirow[b]{3}{*}{ Subgroup $(n)^{\mathrm{a}}$} & \multicolumn{3}{|c|}{ Treatment description } & \multirow{3}{*}{$\begin{array}{l}\text { Number of usable } \\
\text { samples obtained }\end{array}$} \\
\hline & & \multirow[b]{2}{*}{ Agent injected } & \multicolumn{2}{|c|}{ Post-ovulation day of } & \\
\hline & & & Injection & Tissue collection & \\
\hline \multirow[t]{2}{*}{1} & a (6) & Vehicle $^{c}$ & 2 & 4 & 6 \\
\hline & $\mathrm{b}(8)$ & Mifepristone $^{\mathrm{d}}$ & 2 & 4 & 6 \\
\hline \multirow[t]{2}{*}{2} & $\mathrm{a}(7)$ & Vehicle $^{c}$ & 2 & 6 & 7 \\
\hline & $\mathrm{b}(7)$ & Mifepristone $^{\mathrm{d}}$ & 2 & 6 & 6 \\
\hline
\end{tabular}

${ }^{a} n$ values show numbers of animals that yielded preimplantation-stage embryos in the respective subgroups. ${ }^{\mathrm{b}}$ Based on RNA integrity on electrophoresis, yield and RIN score as described in Materials and Methods. Animals that failed to yield preimplantation stage embryos $(n=6)$ and failed to ovulate $(n=2)$ are not shown. ${ }^{c} 2 \mathrm{ml}$, benzyl benzoate: olive oil (1:4), s.c. ${ }^{\mathrm{d}} 2 \mathrm{mg} / \mathrm{kg}$ body weight in $2 \mathrm{ml}$ vehicle, s.c. 

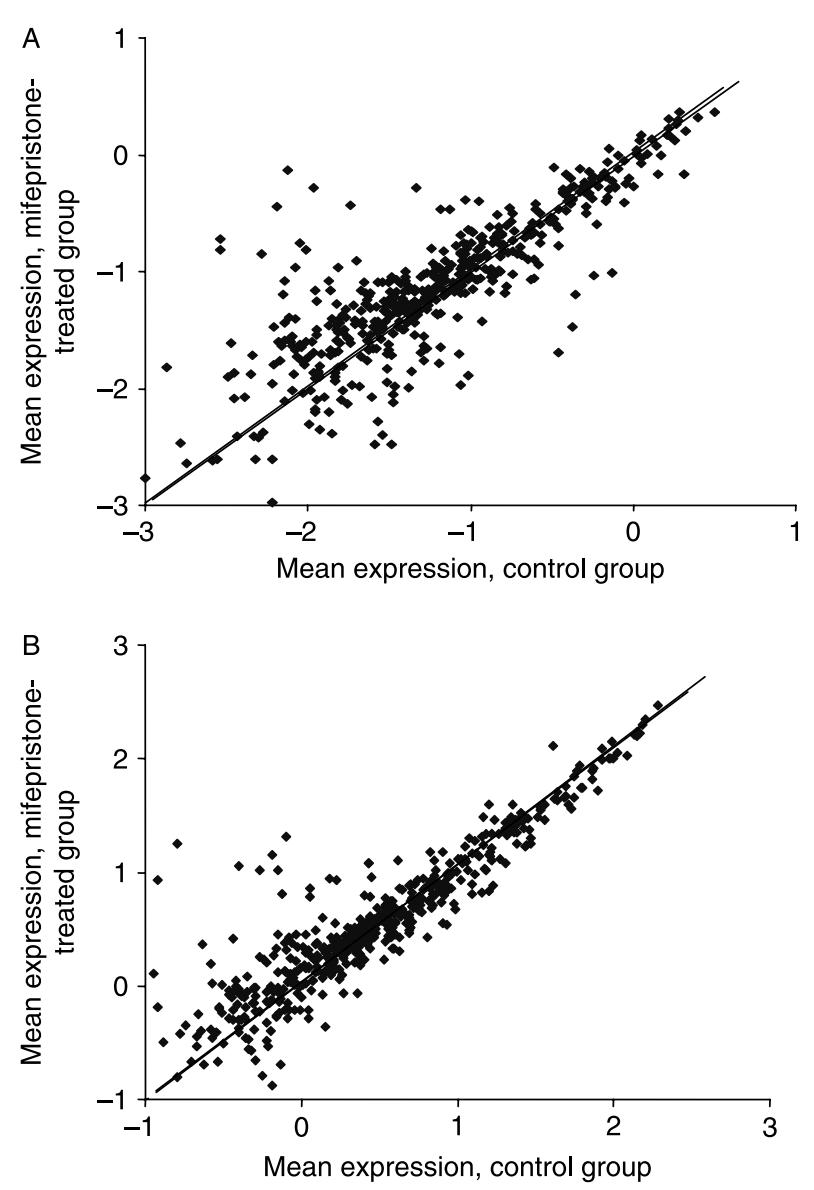

Figure 1 Scattergrams showing microarray analyses comparing the mRNA expression (in logarithmic scale) profiles between control receptive ( $X$-axis) and mifepristone ( $Y$-axis)-treated endometrial samples collected on days 4 (A) and 6 (B) after ovulation. Each point represents normalized mean signal intensities of candidate probes following hybridization.

progressively increase between days 4 and 6 following mifepristone treatment, while an additional $5(\sim 1 \%)$ genes showed differential expression profiles depending on the day after treatment. A different set of $12(3 \%)$ gene products showed changes in day 4 sample only, 10 of them were increased following mifepristone treatment, while another set of $14(\sim 4 \%)$ gene products showed changes only in day 6 samples, 12 of them were increased following mifepristone treatment. We have validated our cDNA array-based data using TaqMan qPCR for nine gene products with observed significant concordance between the two methods. Collectively, it appears that 31 out of 54 gene products with differential expression levels showed changes within fivefold, while residual 23 gene products showed more than fivefold changes in post-ovulation endometrium; however, only four specific gene products showed overlapping between days for the similar levels of fold changes in endometrium following mifepristone treatment. However, the physiological significance of fold changes, as pointed out by Sherwin et al. (2006), remains conjectural. In this way, the systems biology approach in attaching informational value to relative abundance of signals irrespective and independent of its most logical output (Shannon 1949, Laughin 2001) appears to be an attractive proposition in understanding the molecular biology of endometrial receptivity.

Table 6 gives a list of common gene products that appeared to be regulated by progesterone in previous reports and those reported to display differential abundance in the present study. Now, we report for the first time that a new cohort of 28 gene products were affected in implantation-stage endometrium, following early luteal-phase administration of mifepristone in the present study, and those that were not reported to be affected by progesterone in earlier array-based studies using the model of comparative study between prereceptive and receptive stage endometria (Carson et al. 2002, Kao et al. 2002, Borthwick et al. 2003, Riesewijk et al. 2003, Giudice 2004, Horcajadas et al. 2004, Mirkin et al. 2005, Talbi et al. 2006, Sherwin et al. 2007). Out of nine gene products that were subjected to realtime RT-PCR quantification, seven (CD44, CSF1, distal less homeobox 4 (DLX4), enigma, KDR, leptin receptor, macrophage migration inhibitory factor (MIF)) are reported here as novel candidates, while two (mucin 1 (MUC1) and uteroglobin) have been reported earlier (Table 6). While previous reports indicate that wntassociated pathways are involved in progesterone action on endometrial differentiation (Talbi et al. 2006), changes in transcript profiles of homeobox genes like DLX4 and enigma, as well as, of transcription and translation-related gene products like JUNB, JUN, elongation factor $1-\alpha$ (ELF1), ribosomal proteins in implantation stage endometrium following mifepristone treatment have not been reported earlier.

Higher number of copies for transcripts of cyclooxygenase and receptor for prostaglandin F2 on day 6 after ovulation were seen in mifepristone-treated groups. Also, higher transcript levels for TGFB1 and MMPs on both days 4 and 6 , and tissue necrosis factor (TNF) on day 6 after ovulation were seen in the mifepristonetreated group. Relative abundance of transcripts for prolactin receptor and mucin became lower in mifepristone-treated endometrium on days 4 and 6 respectively after ovulation, compared with control endometrium. These factors are known to be regulated in endometrium by progesterone (Salamonsen \& Woolley 1996, Aplin et al. 1998, Ghosh et al. 1998, Nayak et al. 1998, Kim et al. 1999, Marions \& Gemzell-Danielsson 1999, Tseng \& Mazella 1999, Milne \& Jobbour 2003, Lalitkumar et al. 2005a, 2005b, Stavreus-Evers et al. 2005, Critchley et al. 2006, Goff et al. 2006, Slayden \& Brenner 2006, Makino et al. 2007). It may be conjectured that significant changes in the expression of these factors are involved in endometrial hostility in mifepristonetreated endometrium. 
Table 2 Mean fold change in implantation-stage endometrial gene expression in response to mifepristone (2 mg/kg body weight, s.c.) treatment on day 2 after ovulation.

\begin{tabular}{|c|c|c|c|}
\hline \multirow[b]{2}{*}{ Category (Gene name) } & \multirow[b]{2}{*}{ Gene ID } & \multicolumn{2}{|c|}{ Fold change } \\
\hline & & Day 4PO & Day 6PO \\
\hline \multicolumn{4}{|l|}{ Increased on both days } \\
\hline Matrix metalloproteinase 9 & J05070 & $2.1^{\mathrm{a}, *}$ & $3.7^{*}$ \\
\hline STAT3 & L29277 & $2.7^{*}$ & $3.9^{*}$ \\
\hline Kinase domain receptor & NM_002253 & $2.9^{*}$ & $11.0^{+}$ \\
\hline Tastin & U04810 & $4.1^{*}$ & $5.6^{*}$ \\
\hline Ribosomal protein S9 & U14971 & $4.1^{*}$ & $60.5^{+}$ \\
\hline JunB & M29039 & $4.0^{*}$ & $62.5^{+}$ \\
\hline Leptin receptor & U43168 & $15.5^{+}$ & $27.5^{+}$ \\
\hline TGFB1 & X02812 & $74.5^{+}$ & $94.2^{\neq}$ \\
\hline Ribosomal protein S7 & BC061901 & $76.6^{\ddagger}$ & $342.0^{\S}$ \\
\hline \multicolumn{4}{|l|}{$\begin{array}{l}\text { Decreased on both days } \\
\text { None }\end{array}$} \\
\hline \multicolumn{4}{|l|}{ Increased only on day 4} \\
\hline wif & AY358344 & $2.6^{*}$ & - \\
\hline Follistatin-like 1 & M19481 & $2.8^{*}$ & - \\
\hline Tissue factor (thromboplastin) & NM_001993 & $2.9^{*}$ & - \\
\hline Bystin & L36720 & $3.2^{*}$ & - \\
\hline $3 \beta$ hydroxysteroid dehydrogenase & M27137 & $4.7^{*}$ & - \\
\hline Integrin $\alpha-6$ & X53586 & $4.8^{*}$ & - \\
\hline STAT-PIAS $\gamma$ & AF077952 & $6.3^{*}$ & - \\
\hline Keratan sulphotransferase1 & AF219990 & $16.4^{+}$ & - \\
\hline$\alpha-1$ anti-trypsin & K01396 & $32.6^{+}$ & - \\
\hline Matrix metalloproteinase 3 & X05232 & $42.9^{\ddagger}$ & - \\
\hline \multicolumn{4}{|l|}{ Decreased only on day 4} \\
\hline Prolactin receptor & S78505 & $4.4^{*}$ & - \\
\hline ErbB3 & NM_00198 & $7.0^{*}$ & - \\
\hline \multicolumn{4}{|l|}{ Increased only on day 6} \\
\hline Cyclooxygenase (COX) 1 & HSU63846 & - & $2.1^{*}$ \\
\hline Elongation factor $1-\alpha$ & AF458103 & - & $2.2^{*}$ \\
\hline IL6 & X04602 & _- & $2.2 *$ \\
\hline$J A K 1$ & M35203 & - & $2.7^{*}$ \\
\hline Distal less homeobox 4 & NM 138281 & _- & $2.9^{*}$ \\
\hline Tissue necrosis factor- $\alpha$ & X02910 & - & $3.9^{*}$ \\
\hline JUN & NM_002228 & - & $4.0^{*}$ \\
\hline PGF receptor & $\mathrm{L} 24 \overline{4} 70$ & - & $4.8^{*}$ \\
\hline Macrophage inhibitory factor & NM_002415 & - & $6.9^{*}$ \\
\hline CD44 & M59040 & _ & $7.0^{*}$ \\
\hline Thioredoxin & J04026 & - & $7.2^{\dagger}$ \\
\hline Matrix metalloproteinase 10 & X07820 & - & $92.3^{\ddagger}$ \\
\hline \multicolumn{4}{|l|}{ Decreased only on day 6} \\
\hline 17,20 desmolase & U14953 & - & $2.0^{*}$ \\
\hline Mucin 1 & NM_182741 & - & $2.1^{*}$ \\
\hline \multicolumn{4}{|c|}{ Differential responses between days 4 and 6} \\
\hline CSF1 & NM_000757 & $2.3^{\mathrm{a}, *}($ decrease $)$ & $3.6^{*}$ (increase) \\
\hline RASA1 & BC007353 & $2.0^{\mathrm{a}, *}$ (decrease) & $6.5^{*}$ (increase) \\
\hline Uteroferrin & M30284 & $2.6^{*}$ (decrease) & 7.0* (increase) \\
\hline Uteroglobin & $\times 59875$ & $7.0^{*}$ (decrease) & $33.9^{\ddagger}$ (increase) \\
\hline Enigma & BC067806 & $2.4 *$ (increase) & $2.4^{*}$ (decrease) \\
\hline
\end{tabular}

On each day of sampling (day 4 and day 6 post-ovulation; day 4 PO, day 6PO) mifepristone-treated animals were compared with control animals samples on the same day to derive the mean fold change in gene expression. ${ }^{*} P<0.05,{ }^{\dagger} P<0.01,{ }^{\ddagger} P<0.005,{ }^{\S} P<0.001$ between two treatment groups on respective days based on non-parametric analogue of ANOVA followed by Mann-Whitney $U$ test.

${ }^{a}$ Gene expression statistical system for arrays with repeated measures using mixed model method did not identify the change as significant. Table 1 shows the sample details. Gene products shown in bold were subjected to validation test using real-time RT-PCR as shown in Table 4. Twelve gene products shown in italics have been reported earlier by other groups to display differential expression in progesterone-dominated endometrium as shown in Table 6. Twenty-eight gene products showed differential expression between receptive and non-receptive endometria.

CSF1 and IL6 are known to be regulated by progesterone and possess functional linkage with the process of blastocyst implantation (Pollard et al. 1987, Pollard 1997, Sengupta et al. 2003). Leptin receptor is a single-transmembrane-domain receptor of cytokine receptor family and related to IL6ST signal transducing component of IL6 and LIF receptors (Nakashima et al. 1997). This family of peptides has been shown to be involved in the process of mammalian blastocyst implantation (Gonzalez et al. 2000a, 
Table 3 Primers and probes used in the real-time PCR validation of array data.

\begin{tabular}{|c|c|c|}
\hline \multirow[b]{2}{*}{ Candidate gene (GenBank ID) } & \multicolumn{2}{|c|}{ Sequence $\left(5^{\prime}\right.$ to $\left.3^{\prime}\right)$} \\
\hline & Primer $\left(\mathrm{as} / \mathrm{s}, T_{\mathrm{m}}\right)$ & Probes $\left(T_{\mathrm{m}}\right)$ \\
\hline Actin- $\beta(X 00351)$ & $\begin{array}{l}\text { TCTCCTTAATGTCACGCACGATT }(\text { as, } 59.1) \\
\text { GACTACCTCATGAAGATCCTCACC }(\mathrm{s}, 68.9)\end{array}$ & CGGCTACAGCTTCACCACCACGGC (68.9) \\
\hline Leptin receptor (U43168) & $\begin{array}{l}\text { CATAGCGAATCTGGAATTGAAGGT }(\text { as, } 61.2) \\
\text { ACCAACATGTGTCCTTCCTGATT }(\mathrm{s}, 61.0)\end{array}$ & TGGTGAAGCCACTGCСTCCATCCA (68.0) \\
\hline Uteroglobin (X59875) & $\begin{array}{l}\text { TGCTTGTGGTTTATTGAAGAGAGC (as, 61.2) } \\
\text { CCCAACTGCTCCAGCCTCT }(\mathrm{s}, 64.5)\end{array}$ & TGCCATGCTTTGAGTCCACGCCCA (68.0) \\
\hline CSF1 (NM_000757) & $\begin{array}{l}\text { GCCCTCAGTTCCCTCAGAGT }(\mathrm{as}, 64.5) \\
\text { AGCCATCCCTAGCAGTGACC }(\mathrm{s}, 64.5)\end{array}$ & СТСССТСАТСАСССССТСGССС (71.0) \\
\hline MIF (NM_002415) & $\begin{array}{l}\text { ACATATTTCTGGACCCACTCCTC (as, 62.8) } \\
\text { TCATAGCTGACTACTTTGAGACGA }(\mathrm{s}, 61.2)\end{array}$ & CAGCCAGTGCTCCAAGCCCGGT (70.1) \\
\hline CD44 (M59040) & $\begin{array}{l}\text { TGTATTCTCCTTTCTGGACATAGC (as, 61.2) } \\
\text { GCTCCACCTGAAGAAGATTGTAC }(\mathrm{s}, 62.8)\end{array}$ & CAGTCACAGACCTGCCCAATGCCT (68.0) \\
\hline KDR (NM_002253) & $\begin{array}{l}\text { GTGAGAAATCTCTATCTCTCCTGTG (as, 59.5) } \\
\text { CAATACCAGTGCATGTGATGCG }(\mathrm{s}, 58.8)\end{array}$ & ACCAGTACGGCACCACTCAAAC (67.5) \\
\hline MUC1 (NM_182741) & $\begin{array}{l}\text { GAGTGGTGGAGGAGCCTGAA (as, 59.2) } \\
\text { CTCTACTGAGAAGAATGCTGTGAGT }(\mathrm{s}, 59.2)\end{array}$ & ACCAGCAGCGTACTCTCCAGCCAC (67.4) \\
\hline Tastin (U04810) & $\begin{array}{l}\text { TGTATCTCCTACCCCTAGCAAGA (as, 58.5) } \\
\text { GGCGTTGAATATTGAGCGGTG }(\mathrm{s}, 58.6)\end{array}$ & CGGTACGCTCTCAGAAACGCACGC (67.3) \\
\hline Enigma (BC067806) & $\begin{array}{l}\text { GGTGACACACGGGAGTCTTG (as, 58.6) } \\
\text { CGGACAAAACGAGCACAGTG }(\mathrm{s}, 58.1)\end{array}$ & CGCTCGGCAAACGCAGGGTCGA (69.2) \\
\hline
\end{tabular}

as, anti-sense; s, sense.

Cervero et al. 2004), and these peptides act via the JAKSTAT pathway (Gonzalez et al. 2000b). Our data demonstrate that transcripts for JAK-STAT in implantation-stage endometrium were affected by mifepristone treatment. In the present study, we have also observed a consistent involvement of KDR that is known to be operative in mediating the actions of the VEGF peptide family in mammalian endometrium (Krussel et al. 1999). It is however remarkable that the relative abundance of transcripts for IL6, leptin receptor, KDR, JAK, STAT were actually up-regulated in response to mifepristone treatment, contrary to the expected changes based on earlier reports.

Earlier Catalano et al. (2003) observed that JAK1 was reduced at the transcript level in human luteal-phase endometrial explant cultures following mifepristone administration, and immunopositive protein levels of JAK1 were higher in stroma and luminal epithelium of luteal-phase endometrium as compared with other stages of the menstrual cycle. Also, there are reports

Table 4 Real-time qRT-PCR validation of selected candidate gene products.

\begin{tabular}{|c|c|c|c|c|c|}
\hline \multirow[b]{3}{*}{ Candidate } & \multicolumn{4}{|c|}{ Median value (ranges) } & \multirow{3}{*}{$\begin{array}{l}\text { Concordance correlation } \\
\text { coefficient }\left(r_{\mathrm{c}}\right)^{\mathrm{a}}\end{array}$} \\
\hline & \multicolumn{2}{|c|}{ Day 4 after ovulation } & \multicolumn{2}{|c|}{ Day 6 after ovulation } & \\
\hline & Control & Mifepristone & Control & Mifepristone & \\
\hline $\begin{array}{l}\mathrm{KDR} \\
P^{\mathrm{b}}\end{array}$ & $\begin{array}{l}0.95(0.4-1.8) \\
<0.001\end{array}$ & $4.21(2.1-7.7)$ & $\begin{array}{l}1.87(0.6-2.5) \\
<0.001\end{array}$ & $17.84(9.1-33.8)$ & 0.91 \\
\hline $\begin{array}{l}\text { Tastin } \\
P^{\mathrm{b}}\end{array}$ & $\begin{array}{l}0.89(0.3-1.4) \\
<0.001\end{array}$ & $6.71(4.6-10.4)$ & $\begin{array}{l}1.21(0.4-3.4) \\
<0.001\end{array}$ & $14.73(9.6-38.4)$ & 0.80 \\
\hline $\begin{array}{l}\text { Leptin receptor } \\
P^{\mathrm{b}}\end{array}$ & $\begin{array}{l}0.64(0.4-1.9) \\
<0.001\end{array}$ & $11.10(4.7-17.8)$ & $\begin{array}{l}0.71(0.2-1.99) \\
<0.001\end{array}$ & $14.47(5.7-18.3)$ & 0.79 \\
\hline $\begin{array}{l}\text { MIF } \\
P^{\mathrm{b}}\end{array}$ & $\begin{array}{l}1.41(0.4-2.6) \\
<0.4\end{array}$ & $1.92(0.4-4.1)$ & $\begin{array}{l}1.72(0.5-3.2) \\
<0.005\end{array}$ & $13.91(9.1-24.3)$ & 0.92 \\
\hline $\begin{array}{l}\text { CD44 } \\
P^{\mathrm{b}}\end{array}$ & $\begin{array}{l}1.27(0.3-2.3) \\
<0.3\end{array}$ & $1.71(0.3-3.1)$ & $\begin{array}{l}1.09(0.2-1.8) \\
<0.001\end{array}$ & $10.33(5.1-15.7)$ & 0.91 \\
\hline $\begin{array}{l}\text { MUC1 } \\
P^{\mathrm{b}}\end{array}$ & $\begin{array}{l}1.32(0.4-3.3) \\
<0.3\end{array}$ & $0.89(0.2-2.7)$ & $\begin{array}{l}3.67(1.7-9.3) \\
<0.001\end{array}$ & $0.72(0.2-2.8)$ & 0.79 \\
\hline $\begin{array}{l}\text { CSF1 } \\
P^{\mathrm{b}}\end{array}$ & $\begin{array}{l}1.12(0.4-3.5) \\
<0.1\end{array}$ & $0.89(0.2-1.9)$ & $\begin{array}{l}0.77(0.2-1.9) \\
<0.01\end{array}$ & $2.89(1.2-5.1)$ & 0.84 \\
\hline $\begin{array}{l}\text { Uteroglobin } \\
P^{\mathrm{b}}\end{array}$ & $\begin{array}{l}1.11(0.3-2.1) \\
<0.02\end{array}$ & $0.07(0.01-1.1)$ & $\begin{array}{l}1.11(0.3-2.7) \\
<0.001\end{array}$ & $19.1(11.3-37.4)$ & 0.91 \\
\hline $\begin{array}{l}\text { Enigma } \\
P^{\mathrm{b}}\end{array}$ & $\begin{array}{l}0.77(0.2-2.3) \\
<0.001\end{array}$ & $4.32(1.8-8.4)$ & $\begin{array}{l}1.97(0.5-3.6) \\
<0.01\end{array}$ & $0.33(0.07-2.1)$ & 0.81 \\
\hline
\end{tabular}

${ }^{a}$ The estimated concordance correlation coefficient $\left(r_{c}\right)$ between two methods for different gene products were within $95 \%$ of confidence limits (0.74-0.92). ${ }^{\mathrm{b}}$ Friedman test followed by Wilcoxon test for multiple comparison. 


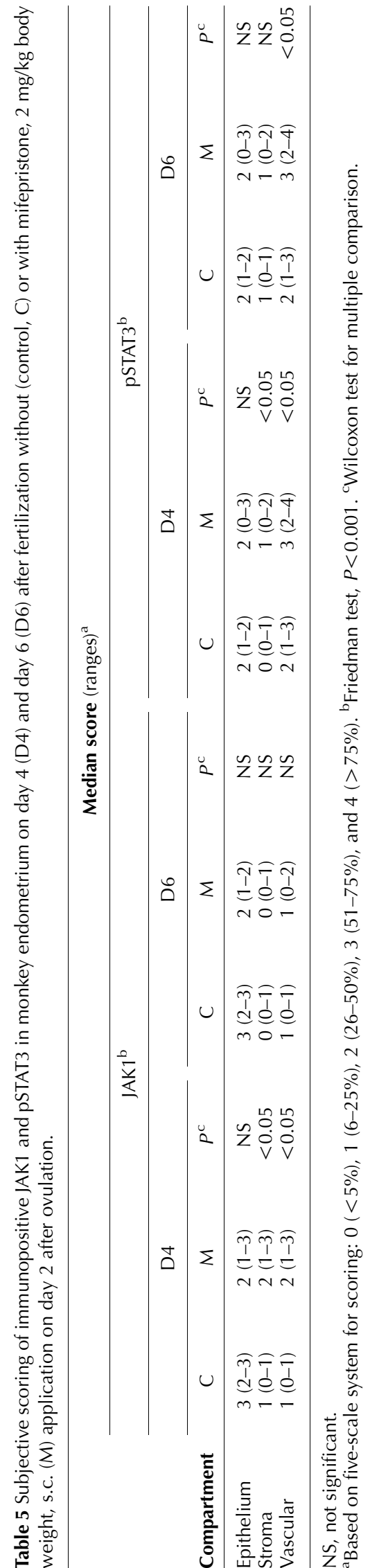

indicating that STAT3 activation in endometrium was associated with endometrial receptivity to implantation in rodents (Liu \& Ogle 2002, Catalano et al. 2005, Nakamura et al. 2006). It appears therefore apparently contradictory that the relative abundance of transcripts for JAK1 and STAT3 were higher in anti-progestin (mifepristone)-treated endometrium in the present study.

In order to further examine this issue, we investigated immunohistochemically the protein products expression for JAK1 and activated STAT3 in endometrial samples collected on days 4 and 6 after ovulation with and without mifepristone treatment. We observed that the immunopositive signals for JAK1 and PSTAT3 were consistently higher in the epithelial compartment compared with the stromal and vascular compartments on days 4 and 6 after ovulation, while mifepristone treatment tended to reverse the profile. It is in fact conjectural whether the observed increasing trend of JAK1 and pSTAT3 proteins in stroma and vessels was indeed related to their higher whole tissue transcript profiles. It is indeed an open issue whether it is sufficiently logical to attempt to draw such a linear relationship between the two processes, namely transcriptomics and proteomics - each involving respective orders of synthesis, turn over and regulation (He 2006). Furthermore, we have reason to believe that input information in the form of relative abundance of transcript elements may not be tightly and digitally linked with the output level (that is protein expression) in a complex system (Segel 2001). As a reviewer has commented that the instance of a vascular gene expression of JAK 1 and activated STAT3 being selectively altered in opposition to their expression behaviour in the epithelium of endometrial tissue with and without mifepristone treatment, as observed in the present study, illustrates the potential limitation of linear extrapolation of whole tissue transcriptomics. Although the proximate mechanism and function of increased expression of JAK1 and activated STAT3 in the vascular compartment following mifepristone treatment are unclear, it is likely that inflammatory changes are triggered in luteal-phase endometrium by mifepristoneinduced vasocentric JAK1-STAT3 pathway (Bromberg 2001, $\mathrm{Ni}$ et al. 2003), thereby rendering endometrial hostility to blastocyst implantation. This observation correlates well with the earlier observation that early luteal-phase administration of mifepristone resulted in significant changes in mid-luteal-phase endometrial vascular physiology along with higher expression of LIF and TGF- $\beta$ in vascular compartment associated with phenotypic hostility of endometrium towards blastocyst implantation (Ghosh et al. 1998).

Our observation that relative transcripts abundance for CD44 and MIF were higher almost to the same extent in endometrial samples only on day 6 following mifepristone application appears intriguing. However, it remains to be studied whether CD44 and MIF 

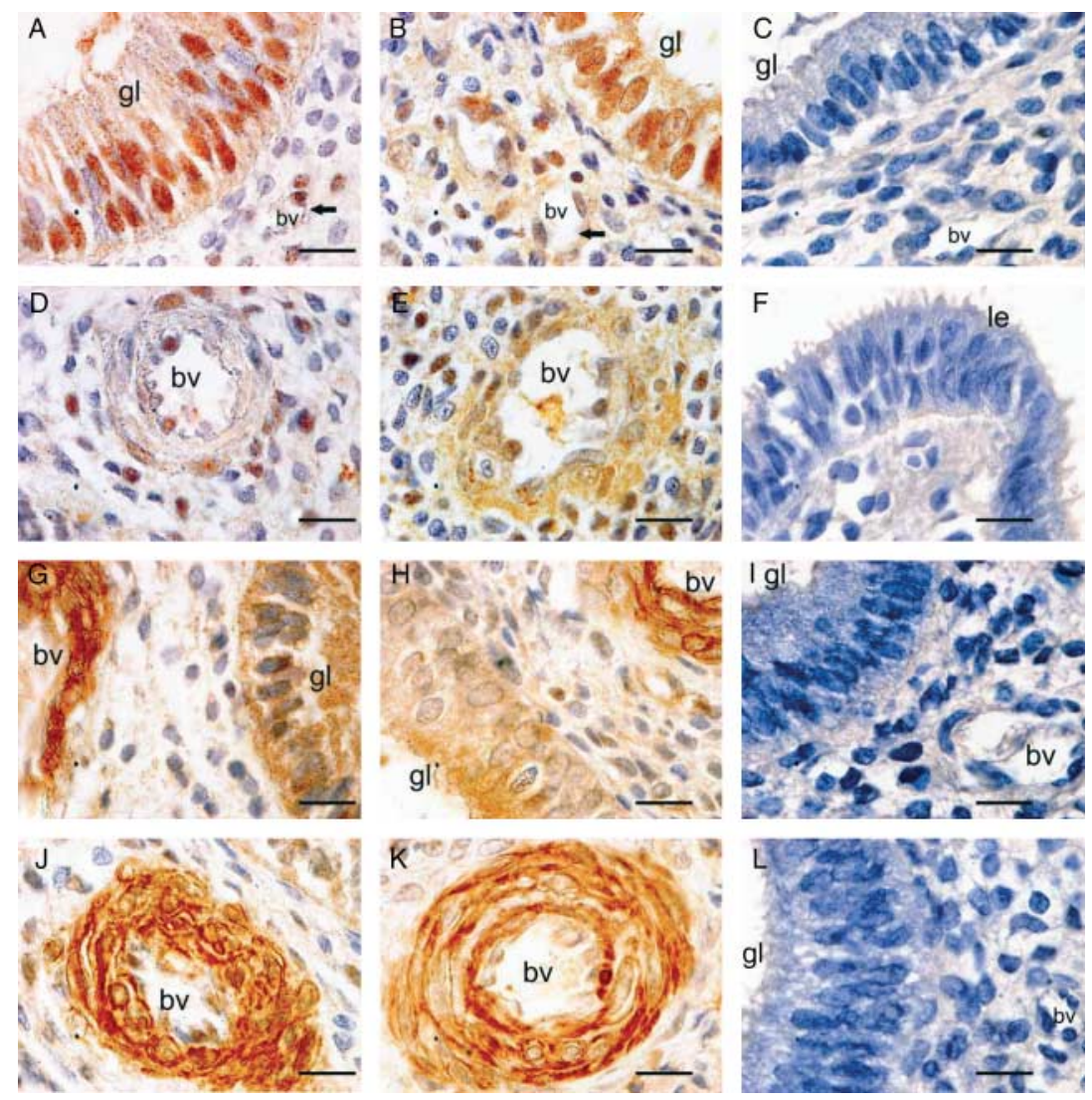

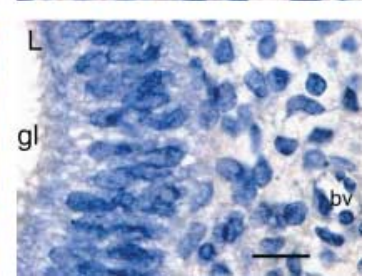

Figure 2 Photomicrographs of immunohistochemical staining for JAK1 (A-F) and pSTAT3 $(\mathrm{G}-\mathrm{L})$ in endometrial tissue samples collected on day 4 after ovulation from control (A, C, D, H, K, and $\mathrm{L}$ ) and mifepristone-treated (B, E, F, G, I, and J) monkeys. Immunostain controls $(\mathrm{C}, \mathrm{F}, \mathrm{I}$, and $\mathrm{L})$ included staining without primary antibody against JAK1 (C), pSTAT3 (I) and respective secondary antibodies ( $\mathrm{F}$ and $\mathrm{L}$ ). Bars $=10 \mu \mathrm{m}$; gl, gland; bv, blood vessel; le, luminal epithelium. are linked with the process of endometrial hostility or compensatory adjustment. CD44 is an integral membrane glycoprotein having two major ligands, hyaluronic acid and osteopontin. It has been suggested that 'hyaladherin' function of CD44 is linked with lymphocyte homing, cell aggregation and growth, while CD44 ligation with osteopontin mediates chemotaxis and invasion (Weber et al. 1996, Afify et al. 2006). Interestingly, CD44 expression increases in the midsecretory human endometrium (Yaegashi et al. 1995, Kar et al. 2004). MIF is a multifunctional and widely distributed protein seemingly involved in several biological activities, especially in processes that are involved in pro-inflammatory physiological mechanism (Hagemann et al. 2007, Vigan et al. 2007). It is notable that such cellular functions that include angiogenesis, cell aggregation and migration, cell growth and proinflammatory changes are markedly evident in the processes related to endometrial receptivity, blastocyst implantation and placentation in the human Bischof 1991, Ghosh \& Sengupta 1998, 2004, Bischof \& Campana 2000), and that the actions of some of these gene products have functional associations with steroid hormone actions in a number of systems (Dupont \& Toussaint 1992, Benson et al. 2004).
Uteroglobin is an anti-inflammatory protein secreted by epithelial cells and its expression in the human uterine endometrium is regulated by progesterone (Becker et al. 1998, Beier \& Beier-Hellwig 1998, Muller-Schottle et al. 1999). Blockade of progesterone action in endometrial cells by mifepristone led to marked up-regulation of uteroglobin gene expression in 'non-receptive' endometrium of rhesus monkeys compared with 'receptive' endometrium. Higher expression of uteroglobin and follistatin-like 1 in dysregulated non-receptive endometrium is likely to reflect the pro-inflammatory type of endometrial response that has been documented following early luteal mifepristone treatment (Ghosh et al. 1996, 1997, Sengupta et al. 2003, Miyamae et al. 2006). Furthermore, it would be interesting to explore whether so-called tumour suppressor-like action of uteroglobin (Zhang et al. 1999) has any bearing on endometrial receptivity and hostility.

In conclusion, we report here that a cohort of 28 gene products were affected in implantation-stage endometrium following early luteal-phase administration of mifepristone and those were not reported to be affected in earlier array-based studies using the model of comparative study between pre-receptive and receptive 


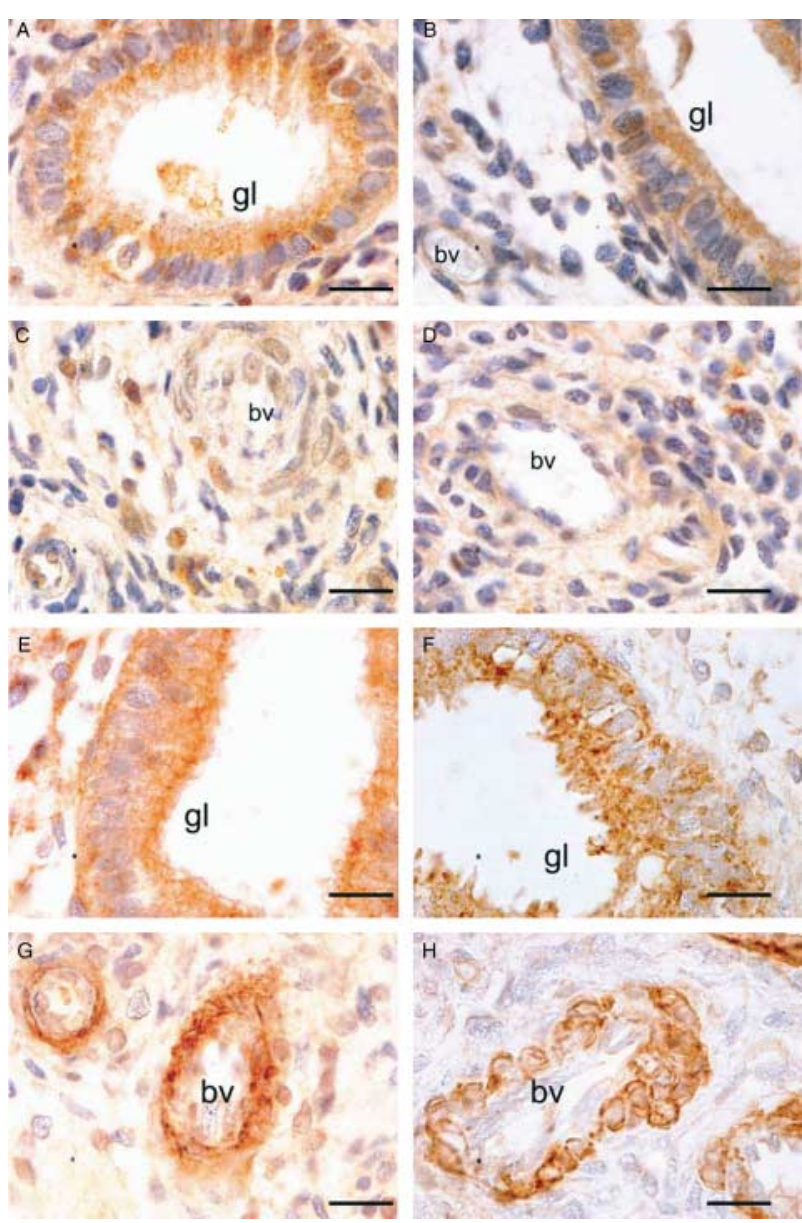

Figure 3 Photomicrographs of immunohistochemical staining for JAK1 (A-D) and pSTAT3 $(\mathrm{E}-\mathrm{H})$ in endometrial tissue samples collected on day 6 after ovulation from control $(A, C, F$, and $H)$ and mifepristone-treated (B, D, E, and G) monkeys. Bars $=10 \mu \mathrm{m}$; gl, gland, bv, blood vessel.

stage endometria. Although most of the novel gene products that were observed to be affected in the present study were already known to be involved in endometrial functionality from previous studies (see Table 7 for details), we are reporting for the first time that these were differentially regulated by high-affinity antiprogestin resulting in implantation failure in the rhesus monkey. Additionally, the observation in the present study that while a cohort of gene expression was consistent between days 4 and 6 after ovulation in a fecund cycle, a group of genes showed specific repression and derepression in the time course makes us to assume that endometrial receptivity in the rhesus monkey is associated with categorical reprogramming in endometrial tanscriptomics as observed in human endometrial fibroblasts in vitro (Brar et al. 2001), human placental villous cytotrophoblasts in vitro (Aronow et al. 2001), and mouse decidual cells (Kashiwagi et al. 2007). We believe that elucidation of the time course pattern of endometrial receptivity associated transcriptomic networks will be beneficial to clinical sciences in improvising strategies to assist the establishment of pregnancy. To this end, it becomes imperative to further perform large-scale transcriptomic studies using prereceptive, receptive and non-receptive endometrial samples from fecund cycles.

\section{Materials and Methods}

\section{General procedures and treatment groups}

Healthy, mature and proven fertile male and female rhesus monkeys (Macaca mulatta) housed in a semi-natural condition at the Primate Research Facility of the All India Institute of Medical Sciences (New Delhi, India) were used in this study. The details of animal selection, housing, management, monitoring of cycles, mating, laparotomy, endometrial sampling, serum collection and immunoassays for serum oestradiol-17 $\beta$ and progesterone have been described elsewhere (Ghosh \& Sengupta 1992, Ghosh et al. 1993, 1996). The study design was approved by the Ethics Committee for the Use of Primates in Biomedical Research of the All India Institute of Medical Sciences.

Female monkeys showing at least two consecutive ovulatory menstrual cycles of normal length (26-32 days) were allocated to one of two groups. Animals $(n=36)$ were allowed to cohabit with proven fertile males during days 8 to 16 of their menstrual cycles. Vaginal smears were checked daily for the presence of spermatozoa. Female monkeys of groups 1 and 2 were injected with either $2 \mathrm{ml}$ vehicle $(1: 4$, benzyl benzoate:olive oil, v/v; $n=18$ ), s.c. only (groups $1 \mathrm{a}$ and $2 \mathrm{a})$, or a single dose of mifepristone $(2 \mathrm{mg} / \mathrm{kg}$ body weight; $n=18$ ), s.c. in the same volume of vehicle (groups $1 \mathrm{~b}$ and $2 \mathrm{~b}$ ) on day 2 after ovulation in mated cycles. The days of ovulation were assessed from the profiles of oestradiol- $17 \beta$ and progesterone in peripheral serum samples as described earlier (Ghosh \& Sengupta 1992, Ghosh et al. 1993, 1996). Steroid immunoassays were performed using methods described elsewhere (Ghosh \& Sengupta 1992, Ghosh et al. 1993, 1996). Two females failed to show clear indication of ovulation and they were removed from the study. Endometrial samples were collected on days 4 (group 1) and 6 (group 2) after ovulation only from mated, ovulatory cycles that had yielded preimplantation-stage embryos (morulae and blastocysts) on uterine flushing as described elsewhere (Ghosh et al. 1997, 2000). The six animals who failed to yield preimplantation-stage embryo were excluded from the study. Table 1 gives the details of different treatment groups from finally selected animals $(n=28)$. Recovered embryos were assessed for their developmental status under stereozoom microscope as described earlier (Sengupta et al. 1989) and were employed in different studies (Ghosh et al. 1997, 2000, Lalitkumar et al. 2005a).

\section{Tissue collection and processing}

The collection and processing of endometrial samples were performed according to the method given elsewhere (Ghosh \& Sengupta 1992, Ghosh et al. 1993, 1996). 
Table 6 Common gene products with differential expressional levels in endometrial tissue during receptivity between previous array-based studies on human and monkey models and the present study.

\begin{tabular}{|c|c|c|c|}
\hline Reference & Subject (no. of gene targets) & Experimental design (sample size) & $\begin{array}{l}\text { Common gene products as } \\
\text { compared with present study }\end{array}$ \\
\hline Kao et al. (2002) & $\begin{array}{l}\text { Normally cycling human } \\
(\sim 12000)\end{array}$ & $\begin{array}{l}\text { Differential array analysis between late proliferative } \\
\text { phase, cycle days } 8-10(n=4) \text { and mid-secretory } \\
\text { phase LH } 8-10(n=7)\end{array}$ & TGF- $\beta$ \\
\hline Carson et al. (2002) & Fertile human $(\sim 12000)$ & $\begin{array}{l}\text { Differential array analysis between early luteal } \\
\text { LH 2-4 }(n=3) \text { and mid-luteal LH 7-9 }(n=3) \\
\text { phases }\end{array}$ & $\begin{array}{l}\text { JunB, PGF-R, TGF- } \beta \text {, prolactin } \\
\text { receptor }\end{array}$ \\
\hline Borthwick et al. (2003) & $\begin{array}{l}\text { Normally cycling human } \\
\quad(\sim 60000)\end{array}$ & $\begin{array}{l}\text { Differential array analysis between proliferative } \\
\text { phase, cycle days } 9-11(n=5) \text { and secretory } \\
\text { phase LH } 6-8(n=5)\end{array}$ & $\begin{array}{l}\alpha-1 \text { anti-trypsin, JUNB, MMP3, } \\
\text { MIF, TGF- } \beta\end{array}$ \\
\hline Catalano et al. (2003) & $\begin{array}{l}\text { Human endometrial explant } \\
\text { culture (1000) }\end{array}$ & $\begin{array}{l}\text { Differential array analysis between mid-secretory } \\
\text { phase }(n=5) \text { endometrial explants treated with } \\
10^{-9} \mathrm{M} \text { oestradiol plus } 10^{-7} \mathrm{M} \text { medroxy-pro- } \\
\text { gesterone acetate and } 10^{-9} \mathrm{M} \text { oestradiol, } 10^{-7} \mathrm{M} \\
\text { medroxy-progesterone acetate plus } 10^{-6} \mathrm{MRU} 486\end{array}$ & JAK1 \\
\hline Riesewijk et al. (2003) & $\begin{array}{l}\text { Normally cycling human } \\
(\sim 12000)\end{array}$ & $\begin{array}{l}\text { Differential array analysis between paired samples } \\
(n=5) \text { collected during pre-receptive LH } 2 \text { and } \\
\text { receptive LH } 7 \text { phases }\end{array}$ & $\alpha-1$ anti-trypsin, Follistatin-like 1 \\
\hline Ace \& Okulicz (2004) & $\begin{array}{l}\text { Ovariectomized hormone } \\
\text { simulated rhesus monkey } \\
(\sim 12000)\end{array}$ & $\begin{array}{l}\text { Differential array analysis of normal proliferative, } \\
\text { day } 13(n=3) \text { and mid-secretory days } 21(n=3) \\
\text { and day } 23(n=3) \text { endometrial samples }\end{array}$ & MMP3, TGF- $\beta$, Uteroglobin \\
\hline Talbi et al. (2006) & $\begin{array}{l}\text { Normally cycling human } \\
(\sim 55000)\end{array}$ & $\begin{array}{l}\text { Differential array analysis of samples collected } \\
\text { during mid-late proliferative }(n=5) \text {, early } \\
(n=3), \text { mid }(n=8) \text { and late }(n=6) \text { secretory } \\
\text { phases of cycle }\end{array}$ & $\begin{array}{l}\text { MUC1, WIF, TGF- } \beta \text {, prolactin } \\
\text { receptor }\end{array}$ \\
\hline Catalano et al. (2007) & $\begin{array}{l}\text { Normally cycling human } \\
\text { (custom made; } 16000)\end{array}$ & $\begin{array}{l}\text { Differential array analysis of } \mathrm{LH}+8 \text { endometrial } \\
\text { samples with no treatment (control; } n=15) \\
\text { and with mifepristone }(200 \mathrm{mg}) \text { treatment at } \\
\text { either } 6 \mathrm{~h}(n=5) \text { or } 24 \mathrm{~h}(n=4)\end{array}$ & Follistatin-like, MMP3, MMP10 \\
\hline Sherwin et al. (2007) & $\begin{array}{l}\text { Adult female baboons } \\
\text { (custom made; 8000) }\end{array}$ & $\begin{array}{l}\text { Differential array analysis of } \mathrm{LH}+10 \text { samples } \\
\text { with either no treatment (control; } n=2) \text { or } \\
\text { rhCG }(1.25 \mathrm{IU} / \mathrm{h}) \text { treatment }(n=2) \text { during } \\
\text { days } 5-10 \text { after ovulation }\end{array}$ & IL6 \\
\hline
\end{tabular}

Briefly, maximally retrievable endometrial samples were collected on days 4 and 6 after ovulation from animals of different treatment groups (Table 1) following laparotomy and fundal hysterotomy under ketamine $(12 \mathrm{mg} / \mathrm{kg}$ body weight; Vetlar, Parke-Davis, Mumbai, India) anaesthesia. Tissue samples were quickly washed in ice-cold PBS to get rid of blood and debris and promptly employed for RNA extraction. An arbitrarily selected small piece from each sample was processed for chemical fixation and preparation of paraffin blocks that were used for immunohistochemistry as described earlier (Ghosh et al. 1998).

\section{RNA extraction}

Total RNA was extracted using Trizol (Agilent Technologies Singapore Pvt. Ltd, Shung Avenue, Singapore) and cleaned up with DNase I (Sigma Chemical Co.) and subjected to re-extraction when it was necessary. The yield and purity of the extracted RNA was checked using standard protocols of absorbance ratio between 260 and $280 \mathrm{~nm}$ and $1 \%$ agarose gel electrophoresis (Farrell 1998). Furthermore, RIN score of individual sample was determined using Agilent 2100 Bioanalyzer, RNA 6000 Nano LabChip kit and Agilent 2100 Expert Software (Agilent Technologies, Inc., Santa Clara, CA, USA) according to a methodology described by Schroeder et al. (2006). Three samples that could not yield either sufficient purity or adequate amount or RIN score above 7 were discarded (Table 1). All accessory chemicals were purchased from Sigma Chemical Co. and Invitrogen (Agilent Technologies Singapur Pvt. Ltd).

\section{Nylon array}

cDNA arrays were produced containing custom-tailored 409 sequence verified clones spotted in duplicate $15 \mathrm{ng}$ each in $200 \mathrm{~nm}$ ) in 576 spots and u.v. cross-linked on a $6 \times 6 \mathrm{~cm}$ nylon membrane along with the quality assurance by the Clontech (Takara Bio Inc., Shiga, Japan). Details of the gene products examined in the present study are given in Supplementary Table 1, which can be viewed online at www.reproductiononline.org/supplemental/.

\section{Complex probe synthesis and array hybridization}

The complex probe synthesis, hybridization and post-hybridization stringency wash were performed according to Catalano et al. (2003). Briefly, radiolabelled cDNA probes were synthesized by labelling $5 \mu \mathrm{g}$ total RNA with $\left[\alpha^{33} \mathrm{P}\right] \mathrm{dATP}$ (Bhava Atomic Research Centre, Hyderabad, India) followed by the removal of unincorporated radioactivity on columns using a kit obtained from Clontech. cDNA probes were denatured and subjected to hybridization at $65^{\circ} \mathrm{C}$ for $16 \mathrm{~h}$ in 
Table 7 Genes showing differential display in the present monkey study and reported to be functional in endometrium in previous reports.

\begin{tabular}{|c|c|}
\hline $\begin{array}{l}\text { Functional classification, } \\
\text { Gene name }\end{array}$ & Reference \\
\hline \multicolumn{2}{|l|}{ Homeobox } \\
\hline $\begin{array}{l}\text { Distal less homeobox } 4 \\
\text { Enigma }\end{array}$ & Quinn et al. (1998a, 1998b) \\
\hline \multicolumn{2}{|c|}{ Transcription/translation associated/housekeeping factors } \\
\hline \multicolumn{2}{|l|}{ Elongation factor $1-\alpha$} \\
\hline \multicolumn{2}{|l|}{ JUNB } \\
\hline \multicolumn{2}{|l|}{ Ribosomal protein S7 } \\
\hline \multicolumn{2}{|l|}{ Ribosomal protein S9 } \\
\hline \multicolumn{2}{|l|}{ Wif } \\
\hline \multicolumn{2}{|l|}{ Cytokines } \\
\hline Colony stimulating factor 1 & Pollard (1997) \\
\hline EGFR & Harris et al. (2005) \\
\hline Follistatin-like 1 & \\
\hline Interleukin 6 & Sengupta et al. (2003) \\
\hline TGFB1 & Ghosh et al. (1998) \\
\hline Tumour necrosis factor $\alpha$ & Lalitkumar et al. (2005a, 2005b) \\
\hline \multicolumn{2}{|l|}{ Receptors } \\
\hline Kinase domain receptor & $\begin{array}{l}\text { Krussel et al. (1999) and Critchley } \\
\text { et al. (2006) }\end{array}$ \\
\hline Leptin receptor & Cervero et al. (2004) \\
\hline Prostaglandin F receptor & Milne \& Jabbour (2003) \\
\hline Prolactin receptor & Tseng \& Mazella (1999) \\
\hline \multicolumn{2}{|l|}{ Signalling factors } \\
\hline JAK1 & Ghosh et al. (2006) \\
\hline STAT3 & $\begin{array}{l}\text { Catalano et al. (2005) and Ghosh } \\
\text { et al. (2006) }\end{array}$ \\
\hline RASA1 & Scambia et al. (1993) \\
\hline \multicolumn{2}{|l|}{ Enzymes } \\
\hline MMP3 & $\begin{array}{l}\text { Salamonsen \& Woolley (1996) } \\
\text { and Slayden \& Brenner (2006) }\end{array}$ \\
\hline MMP9 & Rawdanowicz et al. (1994) \\
\hline MMP10 & Rawdanowicz et al. (1994) \\
\hline $\begin{array}{l}\text { 3- } \beta \text {-hydroxysteroid } \\
\text { dehydrogenase }\end{array}$ & $\begin{array}{l}\text { Seki et al. (1987) and Rhee et al. } \\
\text { (2003) }\end{array}$ \\
\hline Cyclooxygenase 1 & $\begin{array}{l}\text { Kim et al. (1999) and Marions \& } \\
\text { Gemzell-Danielsson (1999) }\end{array}$ \\
\hline 17,20 desmolase & $\begin{array}{l}\text { Seki et al. (1987) and Matsuzaki } \\
\text { et al. (2000) }\end{array}$ \\
\hline \multicolumn{2}{|l|}{ Keratan sulphotransferase } \\
\hline \multicolumn{2}{|l|}{ Adhesion molecules } \\
\hline Bystin & Aoki \& Fukuda (2000) \\
\hline CD44 & Yaegashi et al. (1995) \\
\hline Integrin $\alpha-6$ & Rai et al. (1996) \\
\hline Mucin 1 & Aplin et al. (1998) \\
\hline Tastin & $\begin{array}{l}\text { Suzuki et al. (1999) and Aoki \& } \\
\quad \text { Fukuda (2000) }\end{array}$ \\
\hline \multicolumn{2}{|l|}{ Mediator factors } \\
\hline$\alpha$-anti-trypsin & Marshall \& Braye (1987) \\
\hline MIF & Vigan et al. (2007) \\
\hline Tissue factor, thromboplastin & $\begin{array}{l}\text { Schatz et al. (2000) and Kato et al. } \\
\text { (2005) }\end{array}$ \\
\hline Thioredoxin & Maruyama et al. (1997) \\
\hline Uteroferrin & Gonzalez et al. (1994, 1995) \\
\hline Uteroglobin & Muller-Schottle et al. (1999) \\
\hline
\end{tabular}

hybridization buffer at $1 \times 10^{6}$ c.p.m./ml with the array membrane treated previously with pre-hybridization buffer. The details of hybridization buffer are given elsewhere (Mooney et al. 2000). The hybridized membranes were subjected to step-wise stringency wash in SSC buffer and exposed to low-energy storage phosphor screens (Bio-Rad Laboratories) for $48 \mathrm{~h}$ and scanned at $50 \mu \mathrm{m}$ resolution in a Bio-Rad Molecular Image Fx Scanner (Bio-Rad Laboratories).

\section{Array analysis}

Hybridization signals were quantified using ProArray Analysis software (Bio-Rad Laboratories). Analysis of data retrieved from separate membranes with the same RNA samples yielded QC statistics highly concordant with that of the manufacturer, and it revealed more than $95 \%$ confidence level. In order to screen out biological variation from technical variability, integrated signal analysis for a given membrane was done and signal spots that were low after averaging as compared with background values were removed. Data normalization, averaging, calculation of relative abundance of transcripts, ratio analysis and fold changes were performed on log-transformed data using Arrayassist (Stratagene, North Torey, La Jolla, CA, USA) and GeneSpring (Agilent Technologies). Statistical analysis of data showing more than twofold changes were performed using non-parametric analogue of ANOVA followed by MannWhitney $U$ test to assess the statistical significance of differential expression between groups at $P<0.05$ (Claverie 1999). As suggested in a recent review (Horgan 2007), we have also employed an additional, independent and suitable statistical analysis method with multiple testing correction (mixed model method) having type I error rate set at $<0.01$ (Pan 2002) using Gene Expression Statistical System (GESS, Kaysville, UT, USA) version 2006 for significance analysis of microarrays (http://www-stat.stanford.edu/ tibs/SAM) followed by filtering for more than twofold difference and it was employed to test the power of the results obtained from conventional non-parametric statistical analysis as mentioned above.

\section{Quantitative real-time $R$ T-PCR}

The relative expression of ten selected genes inclusive of actin- $\beta$ as the endogenous control in endometrial samples collected from control and mifepristone treated animals were performed and compared using real-time RT-PCR technology on a Bio-Rad platform (iCycler iQTm Real time PCR detection system, Bio-Rad). $\beta$-Actin was selected as an endogenous control based on its observed expressional consistency in arrays on data analysis. Primers and labelled probes were designed on Beacon Designer software (Labware Scientific Inc., Milipitas, CA, USA) and obtained from Qiagen. Details of primers and probes for target genes are given in Table 3. An optimized kit (Quantitect multiplex PCR kit, Qiagen) was used according to the protocol given by the manufacturer. Briefly, cDNA was synthesized with Superscript II from same total RNA $(5 \mu \mathrm{g})$ samples that were used for the array experiments and levels of select transcripts were estimated by TaqMan analysis for each cDNA sample. Cycle threshold $\left(C_{t}\right)$ values were obtained and $\Delta C_{\mathrm{t}}$ values between experimental $C_{\mathrm{t}}$ and normalization $C_{\mathrm{t}}$ were determined and relative expression ratios between groups were determined using a method described by Pfaffl et al. (2002). Statistical analyses of Q-RT-PCR data from all groups were done using 
Friedman test followed by multiple comparison test based on rank sums Wilcoxon test (Hollander \& Wolfe 1999) using NCSS software version 2007 (Kaysville, UT, USA).

Lin's concordance correlation coefficients $\left(r_{\mathrm{c}}\right)$ between values of transcript abundance obtained from arrays and quantitative RT-PCR for nine selected genes were estimated (Lin 1989) to assess the reproducibility assurance of signal estimation from arrays.

\section{Immunohistochemistry}

Endometrial samples were collected from mated rhesus monkeys yielding preimplantation stage embryos on days 4 and 6 after ovulation following s.c. administration of vehicle (control) or mifepristone ( $2 \mathrm{mg} / \mathrm{kg}$ body weight) as described above. Immunohistochemical staining for detection of JAK1 and activated STAT3 were performed using specific antibodies obtained from Santa Cruz Biotechnology (Santa Cruz, CA, USA) according to the methods provided by the manufacturer. Briefly, deparaffinized and hydrated tissue sections were subjected to microwave heating in $0.1 \mathrm{M}$ sodium citrate buffer ( $\mathrm{pH}$ 6.0) for retrieval of antigens. The endogenous peroxidase activity was quenched and non-specific binding was blocked with non-immune sera as described earlier (Ghosh et al. 1998, Sengupta et al. 2003). Visualization was achieved using Vectastain ABC Peroxidase Elite Kit (Vector Laboratories, Burlingame, CA, USA) and freshly prepared 3,3'-diaminobenzidine tetrahydrochloride (Sigma Chemical Company) as substrate. All immunostaining procedures were performed in a single run along with controls (antibody omission, replacement and neutralization). Immunohistochemically stained sections were subjectively scored for different compartments using a Leica microscope and a standardized five-scale system: 0 (<5\%), 1 (5-25\%), 2 (26-50\%), $3(51-75 \%), 4(>75 \%)$ as described elsewhere (Sengupta et al. 2003). Statistical analyses of the scores were done using Friedman test followed by multiple comparison test based on rank sums Wilcoxon test (Hollander \& Wolfe 1999) using NCSS software version 2007.

\section{Declaration of interest}

The authors declare that there is no conflict of interest that could be perceived as prejudicing the impartiality of the research reported.

\section{Funding}

This research did not receive any specific grant from any funding agency in the public, commercial or not-forprofit sector.

\section{Acknowledgements}

The authors acknowledge the funding supports received from the 'Implantation Research' Initiative of the World Health Organization and the Rockefeller Foundation, and the Department of Science and Technology, Government of India. We thank Dr P G L Lalitkumar and Dr A R Najwa for their support in performing the experiments and Ms M Kalaivani of the Department of Biostatistics for her support in statistical analysis of the data.

\section{References}

Ace CI \& Okulicz WC 2004 Microarray profiling of progesterone-regulated endometrial genes during the rhesus monkey secretory phase. Reproductive Biology and Endocrinology 2 54. DOI:10.1186/14777827-2-54.

Afify AM, Craig S \& Paulino AF 2006 Temporal variation in the distribution of hyaluronic acid, CD44s, and CD44v6 in the human endometrium across the menstrual cycle. Applied Immunohistochemistry \& Molecular Morphology 14 328-333.

Aoki R \& Fukuda MN 2000 Recent molecular approaches to elucidate the mechanism of embryo implantation trophinin, bystin, and tastin as molecules involved in the initial attachment of blastocysts to the uterus in humans. Seminars in Reproductive Medicine 18 265-271.

Aplin JD, Hey NA \& Graham RA 1998 Human endometrial MUC1 carries keratan sulfate: characteristic glycoforms in the luminal epithelium at receptivity. Glycobiology 8 269-276.

Aronow BJ, Richardson BD \& Handweger S 2001 Microarray analysis of trophoblast differentiation: gene expression reprogramming in key gene function categories. Physiological Genomics 6 105-116.

Becker RM, Darrow C, Zimonjie DB, Popescu NC, Watson MA \& Fleming TP 1998 Identification of mammaglobin B, a novel member of the uteroglobin gene family. Genomics 54 70-78.

Beier HM \& Beier-Hellwig K 1998 Molecular and cellular aspects of endometrial receptivity. Human Reproduction Update 4 448-458.

Benson M, Carlsson L, Adner $M$, Jernas $M$, Rudemo $M$, Sjogren A, Svensson PA, Uddman R \& Cardell LO 2004 Gene profiling reveals increased expression of uteroglobin and other anti-inflammatory genes in glucocorticoid-treated nasal polyps. Journal of Allergy and Clinical Immunology 113 1137-1143.

Bischof P 1991 Blastocyst implantation, from the physiology to the experimental model. In Perspectives in Primate Reproductive Biology, pp 69-76. Eds NR Moudgal, K Yoshinaga, AJ Rao \& PR Adiga. New Delhi: Wiley Eastern.

Bischof P \& Campana A 2000 Molecular mediators of implantation. Baillière's Best Practice \& Research. Clinical Obstetrics \& Gynaecology 14 801-814.

Borthwick JM, Charnock-Jones DS, Tom BD, Hull ML, Teirney R, Phillips SC \& Smith SK 2003 Determination of the transcript profile of human endometrium. Molecular Human Reproduction 9 19-33.

Brar AK, Handweger S, Kessier CA \& Aronow BJ 2001 Gene induction and categorical reprogramming during in vitro human endometrial fibroblast decidualization. Physiological Genomics 7 135-148.

Bromberg JF 2001 Activation of STAT proteins and growth control. BioEssays 23 161-169.

Carson DD, Lagow E, Thathiah A, Al-Shami R, Farach-Carson MC, Vernon M, Yuan L, Fritz MA \& Lessey B 2002 Changes in gene expression during the early to mid-luteal (receptive phase) transition in human endometrium detected by high-density microarray screening. Molecular Human Reproduction 8 871-879.

Catalano RD, Yanaihara A, Evans AL, Rocha D, Prentice A, Saidi S, Print CG, Charnock-Jones DS, Sharkey AM \& Smith SK 2003 The effect of RU486 on the gene expression profile in an endometrial explant model. Molecular Human Reproduction 9 465-473.

Catalano RD, Johnson MH, Campbell EA, Charnock-Jones DS, Smith SK \& Sharkey AM 2005 Inhibition of Stat 3 activation in the endometrium prevents implantation: a nonsteroidal approach to contraception. PNAS 102 8585-8590.

Catalano RD, Critchley HO, Heikinheimo O, Baird DT, Hapangama D, Sherwin JRA, Charnock-Jones DS, Smith SK \& Sharkey AM 2007 Mifepristone induced progesterone withdrawal reveals novel regulatory pathways in human endometrium. Molecular Human Reproduction 13 641-654. 
Cervero A, Horcajadas JA, MartIn J, Pellicer A \& Simon C 2004 The leptin system during human endometrial receptivity and preimplantation development. Journal of Clinical Endocrinology and Metabolism 89 2442-2451.

Claverie JM 1999 Computational methods for the identification of differential and coordinated gene expression. Human Molecular Genetics 8 1821-1833.

Critchley HOD, Kelly RW, Baird D \& Brenner RM 2006 Regulation of human endometrial function; mechanisms relevant to uterine bleeding. Reproductive Biology and Endocrinology 4 S55. DOI:10.1186/14777827-4-S1-S5.

Dupont E \& Toussaint C 1992 Immunological effects of corticosteroid in man. Néphrologie 2 27-33.

Edwards RG 1995 Physiological and molecular aspect of implantation. Human Reproduction 10 1-13.

Farrell RE Jr 1998 Electrophoresis of RNA. In RNA Methodologies - a Laboratory Guide for Isolation and Characterization, edn 2, pp 174-177. USA: Academic press.

Gemzell-Danielson K, Swahn ML, Svanlander P \& Bygdeman M 1993 Early luteal phase treatment with mifepristone (RU486) for fertility regulation. Human Reproduction 8 870-873.

Ghosh D \& Sengupta J 1992 Patterns of ovulation, conception and pre-implantation embryo development during the breeding season in rhesus monkeys kept under semi-natural conditions. Acta Endocrinologica 127 168-173.

Ghosh D \& Sengupta J 1993 Anti-nidatory effect of a single, early postovulatory administration of mifepristone (RU 486) in the rhesus monkey. Human Reproduction 8 552-558.

Ghosh D \& Sengupta J 1995 Endometrial receptivity for implantation: another look at the issue of preimplantation oestrogen. Human Reproduction 10 1-2.

Ghosh D \& Sengupta J 1998 Recent developments in endocrinology and paracrinology of blastocyst implantation in the primate. Human Reproduction Update 4 153-168.

Ghosh D \& Sengupta J 2004 Endocrine and paracrine correlates of endometrial receptivity to blastocyst implantation in the human. Indian Journal of Physiology and Pharmacology 48 6-30.

Ghosh D, Roy A, Sengupta J \& Johannisson E 1993 Morphological characteristics of preimplantation stage endometrium in the rhesus monkey. Human Reproduction 8 1579-1587.

Ghosh D, Sengupta J \& Hendrickx AG 1996 Effect of single-dose, early luteal phase administration of mifepristone (RU486) on implantation stage endometrium in the rhesus monkey. Human Reproduction 11 2026-2035.

Ghosh D, Kumar PGL \& Sengupta J 1997 Early luteal phase administration of mifepristone inhibits preimplantation embryo development and viability in the rhesus monkey. Human Reproduction 12 575-582.

Ghosh D, Lalitkumar PGL \& Sengupta J 1998 Effect of early luteal phase administration of mifepristone (RU486) on leukemia inhibitory factor, transforming growth factor and vascular endothelial growth factor in the implantation stage endometrium of the rhesus monkey. Journal of Endocrinology 157 115-125.

Ghosh D, Lalitkumar PG, Wong VJ, Hendrickx AG \& Sengupta J 2000 Preimplantation embryo morphology following early luteal phase anti-nidatory treatment with mifepristone (RU486) in the rhesus monkey. Human Reproduction 15 180-188.

Ghosh D, Najwa AR \& Sengupta J 2006 In vitro action of leukemia inhibitory factor (LIF) on mid-secretory stage endometrial stromal cells collected from hormone-simulated, ovariectomized monkey and maintained in three-dimensional primary culture. Indian Journal of Physiology and Pharmacology 50 355-366.

Giudice LC 2004 Microarray expression profiling reveals candidate genes for human uterine receptivity. American Journal of Pharmacogenomics 4 299-312.

Goff AK, Jamshidi AA \& Komba A 2006 Inhibition of prostaglandin F2 alpha synthesis and oxytocin receptor by progesterone antagonist in bovine endometrial cells in vitro. Steroids 71 785-791.

Gonzalez BY, Michel FJ \& Simmen RC 1994 A regulatory element within the uteroferrin gene $5^{\prime}$-flanking region binds a pregnancy-associated uterine endometrial protein. DNA and Cell Biology 13 365-376.
Gonzalez BY, Perera OP, Michel FJ \& Simmen RC 1995 Multiple upstream promoter elements of the gene for the pregnancy-associated tartrate-resistant acid phosphatase, uteroferrin bind human endometrial nuclear proteins. Molecular and Cellular Endocrinology 108 51-65.

Gonzalez RR, Caballero-Campo P, Jasper M, Mercader A, Devoto L, Pellicer A \& Simon C 2000a Leptin and leptin receptor are expressed in the human endometrium. Leptin secretion is differentially regulated by human blastocyst in endometrial epithelial cells. Journal of Clinical Endocrinology and Metabolism 85 14848-14883.

Gonzalez RR, Simon C, Caballero-Campo P, Norman R, Chardonnens D, Devoto L \& Bischof P 2000b Leptin and reproduction. Human Reproduction Update 6 290-300.

Hagemann T, Robinson SC, Thompson RG, Charles K, Kulbe H \& Balkwill FR 2007 Ovarian cancer cell-derived migration inhibitory factor enhances tumor growth, progression, and angiogenesis. Molecular Cancer Therapeutics 6 1993-2002.

Harris HA, Bruner-Trans KL, Zhang X, Osteen KG \& Lyttle CR 2005 A selective estrogen receptor-beta agonist causes lesion regression in an experimentally induced model of endometriosis. Human Reproduction 20 936-941.

He YD 2006 Genomic approach to biomarker identification and its recent application. Cancer Biomarkers 2 103-133.

Hendrickx AG \& Enders AC 1980 Implantation in non-human primates-II. In Non-Human Primates Models for the Study of Human Reproduction, pp 109-115. Ed. TC Anand Kumar. Basel: Karger.

Hollander M \& Wolfe DA 1999 Nonparametric Statistical Methods, New York: John Wiley, pp. 270-361.

Horcajadas JA, Riesewijk A, Martin J, Cervero A, Mosselman S, Pellicer A \& Simon C 2004 Global gene expression profiling of human endometrial receptivity. Journal of Reproductive Immunology 63 41-49.

Horgan GW 2007 Sample size and replication in 2D gel electrophoresis studies. Journal of Proteome Research 6 2884-2887.

Kao LC, Tulac S, Lobo S, Imani B, Yang JP, Germeyer A, Osteen K, Taylor RN, Lessey BA \& Giudice LC 2002 Global gene profiling in human endometrium during the window of implantation. Endocrinology 143 2119-2138.

Kar M, Sengupta J, Kumar S, Bhargava VL \& Ghosh D 2004 Immunohistochemical localization of macrophage CD68+, HLA-DR +, L1 + and CD44+subsets in uterine endometrium during different phases of menstrual cycle. Indian Journal of Physiology and Pharmacology $\mathbf{4 8}$ 293-303.

Kashiwagi A, DiGirolamo CM, Kanda Y, Niikura Y, Esmon CT, Hansen TR, Shioda T \& Pru JK 2007 The postimplantation embryo differentially regulates endometrial gene expression and decidualization. Endocrinology 148 4173-4184.

Kato S, Pinto M, Carvajal A, Espinoza N, Monsó C, Bravo L, Villalon M, Cuello M, Quest AF, Suenaga A et al. 2005 Tissue factor is regulated by epidermal growth factor in normal and malignant human endometrial epithelial cells. Thrombosis and Haemostasis 94 444-453.

Kim JJ, Wang J, Bambra C, Das SK, Dey SK \& Fazleabas AT 1999 Expression of cyclooxygenase- 1 and -2 in the baboon endometrium during the menstrual cycle and pregnancy. Endocrinology 140 2672-2678.

Krussel JS, Casan EM, Raga F, Hirchehain J, Wen Y, Huang H-Y, Bielfeld P \& Polan ML 1999 Expression of mRNA for vascular endothelial growth factor transmembraneous receptors FLT-1 and KDR and the soluble receptor s-flt in cycling human endometrium. Molecular Human Reproduction 5 452-458.

Lalitkumar PGL, Sengupta J \& Ghosh D 2005a Endometrial tumor necrosis factor (TNF) is a likely mediator of early luteal phase mifepristonemediated negative effector action on the preimplantation embryo. Reproduction 129 323-335.

Lalitkumar PGL, Sengupta J \& Ghosh D 2005b Effect of tumour necrosis factor-alpha (TNF-alpha) on protein synthesis by mouse preimplantation stage embryos in vitro. Indian Journal of Physiology and Pharmacology 49 139-147.

Laughin SB 2001 Efficiency and complexity in neural coding. In Complexity in Biological Information Processing, pp 177-192. Eds G Bock \& J Goode. New York: John Wiley.

Lin L I-K 1989 A concordance correlation coefficient to evaluate reproducibility. Biometrics 45 255-268. 
Liu T \& Ogle TF 2002 Signal transducer and activator of transcription 3 is expressed in the decidualized endometrium of pregnancy and associates with progesterone receptor through protein-protein interactions. Biology of Reproduction 67 114-118.

Makino S, Zaragoza DB, Mitchell BF, Robertson S \& Olson DM 2007 Prostaglandin F2 alpha and its receptor as activators of human deciduas. Seminars in Reproductive Medicine 25 60-68.

Marions L \& Gemzell-Danielsson K 1999 Expression of cyclo-oxygenase in human endometrium during the implantation period. Molecular Human Reproduction 5 961-965.

Marshall RJ \& Braye SG 1987 Immunohistochemical demonstration of alpha-1-antitrypsin and alpha-1-antichymotrypsin in normal human endometrium. International Journal of Gynecological Pathology 6 49-54.

Maruyama T, Kitaoka Y, Sachi Y, Nakanoin K, Hirota K, Shiozawa T, Yoshimura Y, Fujii S \& Yodoi J 1997 Thioredoxin expression in the human endometrium during the menstrual cycle. Molecular Human Reproduction 3 989-993.

Matsuzaki S, Yanase T, Murakami T, Uehara S, Nawata H \& Yajima A 2000 Induction of endometrial cycles and ovulation in a woman with combined 17alpha-hydroxylase/17,20-lyase deficiency due to compound heterozygous mutations on the p45017alpha gene. Fertility and Sterility 73 1183-1186.

Milne SA \& Jabbour HN 2003 Prostaglandin (PG) F(2alpha) receptor expression and signaling in human endometrium: role of PGF(2alpha) in epithelial cell proliferation. Journal of Clinical Endocrinology and Metabolism 88 1825-1832.

Mirkin S, Arslan M, Churikov D, Corica A, Diaz JI, Williams S, Bocca S \& Oehninger S 2005 In search of candidate genes critically expressed in the human endometrium during the window of implantation. Human Reproduction 20 2104-2117.

Miyamae T, Marinov AD, Sowders D, Wilson DC, Devlin J, Boudreau R, Robbins P \& Hirsch R 2006 Follistatin-like protein-1 is a novel proinflammatory molecule. Journal of Immunology 177 4758-4762.

Mooney JL, Kayne PS, O' Brien SP \& Debouck CM 2000 Construction and application of gene microarrays on nylon membranes. In Differential Display, pp 169-198. Eds RA Leslie \& HA Robertson. New York: Oxford University Press.

Muller-Schottle F, Classen-Linke I, Alfer J, Krusche C, Beier-Hellwig K, Sterzik K \& Beier HM 1999 Expression of uteroglobin in the human endometrium. Molecular Human Reproduction 5 1155-1161.

Nakamura H, Kimura T, Koyama S, Ogita K, Tsutsui T, Shimoya K, Taniguchi T, Koyama M, Kaneda Y \& Murata Y 2006 Mouse model of human infertility: transient and local inhibition of endometrial STAT-3 activaton results in implantation failure. FEBS Letters 580 2717-2722.

Nakashima K, Narazaki M \& Taga T 1997 Leptin receptor (OB-R) oligomerizes with itself but not with its closely related cytokine signal transducer gp130. FEBS Letters 403 79-82.

Nayak NR, Sengupta J \& Ghosh D 1998 Antinidatory effect of luteal phase administration of Mifepristone (RU486) is associated with changes in endometrial prostaglandins during the implantation window. Contraception 58 111-117.

Ni CW, Hsieh HJ, Chao YJ \& Wang DL 2003 Shear flow attenuates serum induced STAT3 activation in endothelial cells. Journal of Biological Chemistry 278 19702-19708.

Pan W 2002 A comparative review of statistical methods for discovering differently expressed genes in replicated microarray experiments. Bioinformatics 18 546-554.

Pfaffl MW, Horgan GW \& Dempfle L 2002 Relative expression software tool (REST) for group-wise comparison and statistical analysis of relative expression results in real-time PCR. Nucleic Acids Research 30 e36 (1-10).

Pollard JW 1997 Role of colony-stimulating factor-1 in reproduction and development. Molecular Reproduction and Development 46 54-60.

Pollard JW, Bartocci A, Arceci R, Orlofsky A, Ladner MB \& Stanley ER 1987 Apparent role of the macrophage growth factor, CSF-1, in placental development. Nature 330 484-486.

Quinn LM, Kilpatrick LM, Latham SE \& Kalionis B 1998a Homeobox genes DLX4 and HB24 are expressed in regions of epithelial-mesenchymal cell interaction in the adult human endometrium. Molecular Human Reproduction 5 497-501.
Quinn LM, Latham SE \& Kalionis B 1998 b A distal-less class homeobox gene, DLX4, is a candidate for regulating epithelial-mesenchymal cell interactions in the human placenta. Placenta 19 87-93.

Rai V, Hopkisson J, Kennedy S, Bergqvist A, Barlow DH \& Mardon HJ 1996 Integrins alpha 3 and alpha 6 are differentially expressed in endometrium and endometriosis. Journal of Pathology 80 181-187.

Rawdanowicz TJ, Hampton Al, Nagase H \& Woolley DE 1994 Matrix metalloproteinase production by cultured human endometrial stromal cells: identification of interstitial collagenase, gelatinase-A, gelatinase-B, and stromelysin-1 and their differential regulation by interleukin-1alpha and tumor necrosis factor-alpha. Journal of Clinical Endocrinology and Metabolism 79 530-536.

Rhee HS, Oh SH, Ko BJ, Han DM, Jeon BH, Park H, Moon HB \& Kim WS 2003 Expression of 3 beta-hydroxysteroid dehydrogenase and P450 side chain cleavage enzyme in the human uterine endometrium. Experimental and Molecular Medicine 3 160-166.

Riesewijk A, Martin J, van Os R, Horcajadas JA, Polman J, Pellicer A, Mosselman S \& Simon C 2003 Gene expression profiling of human endometrial receptivity on days $\mathrm{LH}+2$ versus $\mathrm{LH}+7$ by microarray technology. Molecular Human Reproduction 9 253-264.

Salamonsen LA \& Woolley DE 1996 Matrix metalloproteinases in normal menstruation. Human Reproduction 11 124-132.

Scambia G, Catozzi L, Benedetti-Panici P, Ferrandina G, Battaglia F, Giovannini G, Distefano M, Pellizzola D, Piffanelli A \& Mancuso S 1993 Expression of ras p21 oncoprotein in normal and neoplastic human endometrium. Gynecologic Oncology 50 339-346.

Schatz F, Soderland C, Hendricks-Muñoz KD, Gerrets RP \& Lockwood CJ 2000 Human endometrial endothelial cells: isolation, characterization, and inflammatory-mediated expression of tissue factor and type 1 plasminogen activator inhibitor. Biology of Reproduction 62 691-697.

Schroeder A, Mueller O, Stocker S, Salowsky R, Leibel M, Gassmann M, Lightfoot S, Menzel W, Granzow M \& Ragg T 2006 The RIN: an RNA integrity number for assigning integrity values to RNA measurements. BMC Molecular Biology 7 3. DOI:10.1186/471-2199/7/3.

Segel LA 2001 Controlling the immune system: diffuse feedback via a diffuse informational network. In Complexity in Biological Information Processing, pp 177-192. Eds G Bock \& J Goode. New York: John Wiley.

Seki M, Hara Y, Sekiya M, Itagaki T, Hirato K, Yanaihara T \& Nakayama T 1987 Changes in steroid enzyme activity in the human endometrium during the menstrual cycle. Nippon Sanka Fujinka Gakkai Zasshi 39 1571-1578.

Sengupta J, Talwar D, Paria BC \& Ghosh D 1989 Is there any $\Delta^{5}$-3beta hydroxysteroid dehydrogenase activity in preimplantation embryo of rhesus monkey? Indian Journal of Experimental Biology 27 417-420.

Sengupta J, Dhawan L \& Ghosh D 2003 Immunohistochemical localization of Leukemia inhibitory factor, interleukin 1 and 6 at the primary implantation site in the rhesus monkey. Cytokine 24 277-285.

Shannon CE 1949 Communication in presence of noise. Proceedings of Institute of Radio Engineering 37 10-21.

Sherwin R, Catalano R \& Sharkey A 2006 Large-scale gene expression studies of the endometrium: what have we learnt? Reproduction 132 $1-10$.

Sherwin JR, Sharkey AM, Cameo P, Mavrogianis PM, Catalano RD, Edassery S \& Fazleabas AT 2007 Identification of novel genes regulated by chorionic gonadotropin in baboon endometrium during the window of implantation. Endocrinology 148 618-626.

Simon C \& Dominguez F 2004 Embryonic-endometrial interactions at implantation in humans. Gynecologic and Obstetric Investigation 57 28-30.

Simon C, Martin JC \& Pellier A 2000 Paracrine regulators of implantation. Baillière's Best Practice \& Research. Clinical Obstetrics \& Gynaecology 14 815-826.

Slayden Ov D \& Brenner RM 2006 A critical period of progesterone withdrawal precedes menstruation in macaques. Reproductive Biology and Endocrinology 4 S56. DOI:10.1186/1477-7827-4-S1-S6.

Stavreus-Evers A, Koraen L, Scott JE, Zhang P \& Westlund P 2005 Distribution of cycloxygenase-1 cyclooxegenase-2, and cytosolic phospholipase A2 in the luteal phase endometrium and ovary. Fertility and Sterility 83 156-162.

Suzuki N, Nakayama J, Shih IM, Aoki D, Nozawa S \& Fukuda MN 1999 Expression of trophinin, tastin, and bystin by trophoblast and endometrial cells in human placenta. Biology of Reproduction 60 621-627. 
Talbi S, Hamilton AE, Vo KC, Tulac S, Overgaard MT, Dosiou C, Le Shay N, Nezhat CN, Kempson R, Lessey BA et al. 2006 Molecular phenotyping of human endometrium distinguishes menstrual cycle phases and underlying biological processes in normo-ovulatory women. Endocrinology 147 1097-1121.

Tseng L \& Mazella J 1999 Prolactin and its receptor in human endometrium. Seminars in Reproductive Endocrinology 17 23-27.

Vigan AP, Cintorino M, Schatz F, Lockwood CJ \& Arcuri F 2007 The role of macrophage migration inhibitory factor in maintaining the immune privilege at the fetal-maternal interface. Seminars in Immunopathology 9 135-150.

Weber GF, Ashkar S, Glimeher MJ \& Cantor H 1996 Receptor-ligand interaction between CD44 and osteopontin (Eta1). Science 271 509-512.
Yaegashi N, Fujita N, Yajima A \& Nakamura M 1995 Menstrual cycle dependent expression of CD44 in normal human endometrium. Human Pathology 26 862-865.

Zhang Z, Khund GC, Panda D, Mandal AK, Mantile-Selvaggi G, Peri A, Chiun-Jye Y \& Mukherjee AB 1999 Loss of transforming phenotype in cancer cells by overexpression of the uteroglobin gene. PNAS 96 3963-3968.

Received 21 October 2008

First decision 4 December 2008

Revised manuscript received 29 April 2009

Accepted 13 May 2009 